\title{
Management of Lung Abscess : Review of 50 cases in Al- Hussein Teaching Hospital / Thi-Qar ( 2013-2018 )
}

\author{
Dr. Ahmed Abdulameer Daffar ( MBChB, FIBMS Thoracic and Cardiovascular \\ Surgery ) \\ drahmeddaffar1979@gmail.com
}

Dr. Riyadh Mohammad Salih ( FIBMS Nephrology, FIBMS Medicine )

riyadhmohammed34@gmail.com

\author{
Dr. Rafid Remthan Hussein Al-Temimi ( MBChB, CAMB, DMRD ) \\ Rafid.altemimi2@gmail.com
}

\begin{abstract}
Background: Lung abscess is a type of liquefactive necrosis of the lung tissue and formation of cavities (more than $2 \mathrm{~cm}$ ) containing necrotic debris or fluid caused by microbial infection. It can be caused by aspiration, which may occur during altered consciousness and it usually causes a pus-filled cavity. Moreover, alcoholism is the most common condition predisposing to lung abscesses.
\end{abstract}

Aim: To present the effectiveness of conservative treatment in lung abscess and the rare indication of surgery for such disease in AL-Hussein teaching hospital in Thi-Qar Governorate and to compare our study with other study in Iraq and abroad Iraq.

Patients and Methods: This is a retrospective study of 50 patients suffering from lung abscess over a period of 5 years from the first of May 2013 till the first May 2018 in ALHussein teaching hospital in Thi-Qar governorate. The patient was admitted and received heavy antibiotics intravenously. In addition, good hydration was provided and also mucolytics, analgesic and antipyretic drugs were given along with good physiotherapy. Management continued on an inpatient basis for an average of 7 days. Follow up continued on an outpatient basis.

Results: Males and and females were affected nearly equally. The ages affected ranged from ( $10-60$ ) years at presentation. $80 \%$ of the patients suffered from cough and most of our patients ( $90 \%$ ) had anorexia and fever.

Conservative management was very effective in more than $90 \%$ of patients with lung abscess.

Conclusions: Lung abscess was treated in most cases by conservative measures.

All patients received initially injectable antibiotics and the treatment may continue for several weeks to several months. Hemoptysis was recorded in several patients only.

Recommendations: Treatment should always begin by injectable antibiotics. Co-morbidities should be treated simultaneously with lung abscess. Malignancy should always be excluded 
ISSN (Print):1992-92 18, ISSN (Online):1992-92 18

DOI: https://doi.org/10.32792/utq/utjmed/19/1/4/0

especially in old aged people. Surgery is indicated only when conservative measures fail.

\section{INTRODUCTION}

Is a type of liquefactive necrosis of the lung tissue and formation of cavities (more than $2 \mathrm{~cm}$ ) containing necrotic debris or fluid caused by microbial infection. It can be caused by aspiration, which may occur during altered consciousness and it usually causes a pus-filled cavity. Moreover, alcoholism is the most common condition predisposing to lung abscesses.

Lung abscess is considered primary
(60\%) when it results from existing lung parenchymal process is termed secondary when it complicates another process like, vascular emboli or follows rupture of extrapulmonary abscess into lung.

There are several imaging techniques which can identify the material inside the thorax such as computerized tomography (CT) scan of the thorax and ultrasound of the thorax as in figure $^{(\mathbf{1})}$.

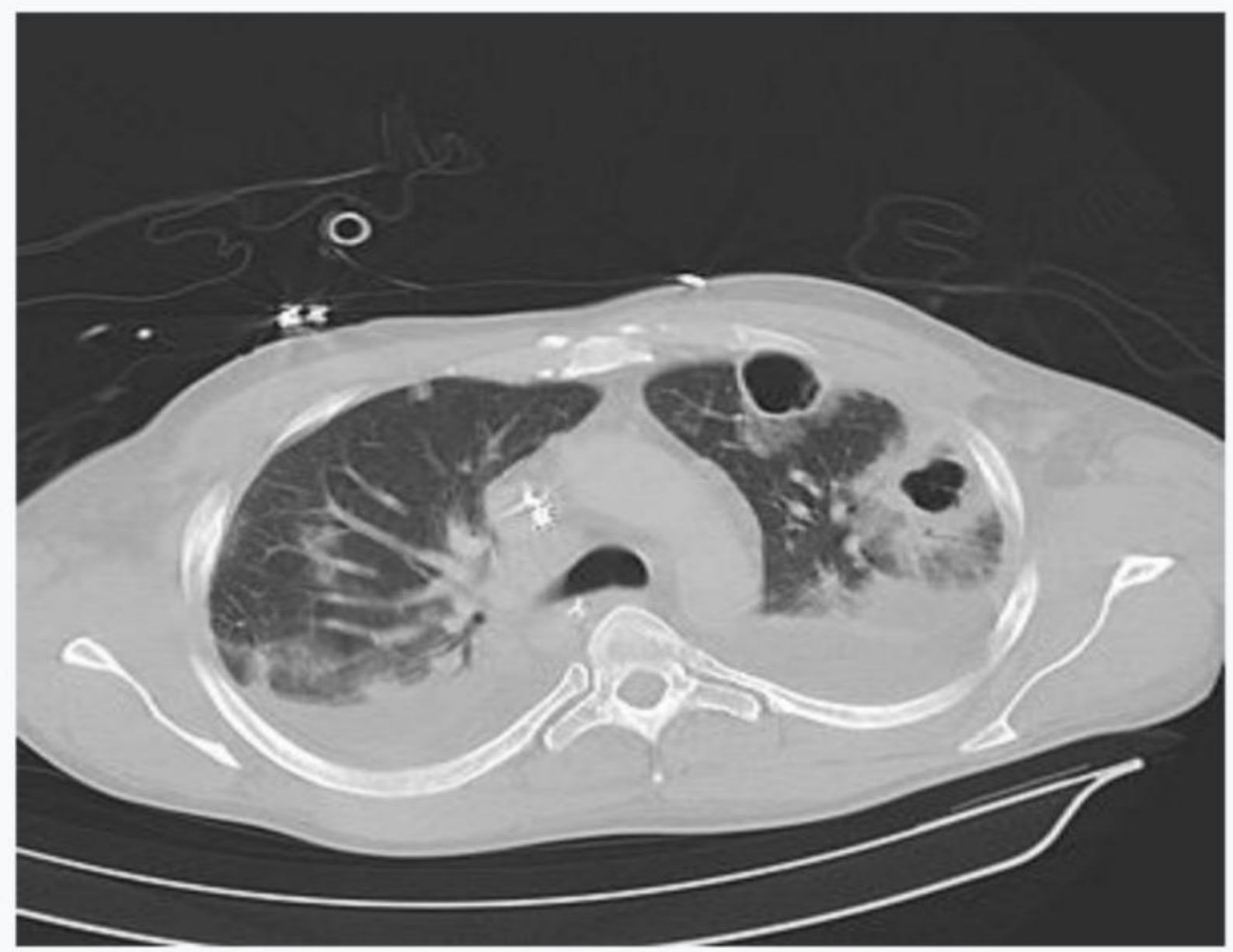

Figure(1): Represent computed tomography(CT) scan of chest showing bilateral pneumonia with abscess, effusions, and caverns in 37 year-old male. 
Broad spectrum antibiotic to cover mixed flora is the mainstay of treatment. Pulmonary physiotherapy and postural drainage are also important. Surgical procedures are required in selective patients for drainage or pulmonary resection ${ }^{(\mathbf{1})}$.

\section{Classification of lung abscesses}

1-According to the duration:

A. Acute (less than 6 weeks).

B. Chronic (more than 6 weeks).

2- According to etiology:

A. Primary (aspiration of oropharyngeal secretions, necrotizing pneumonia, immunodeficiency).

B. Secondary

(bronchial obstructions, haematogenic dissemination, direct spreading from mediastinal infection, from subphrenium, coexisting lung diseases).

3-According to way of spreading:

A. Brochogenic (aspiration of oropharyngeal secretions, bronchial obstruction by tumor, foreign body, enlarged lymph nodes, congenital malformation).

B. Haematogenic (abdominal sepsis, infective endocarditic, septic thromboembolisms).

Acute lung abscess is usually circumscribed with not so welldefined surrounding to lung parenchyma, fulfilled with thick necrotic detritus. Histologically, in central parts of abscess there are necrotic tissue mixed with necrotic granulocytes and bacteria. Around this area there are preserved neutrophillic granulocytes with dilated blood vessels and inflammatory edema.

Contributing factors for lung abscess are include: Elderly, dental/peridental infections (gingivitis-with bacterial concentration $>10^{11} / \mathrm{mL}$ ), alcoholism, drug abuse, diabetes mellitus, coma, artificial ventilation, convulsions, neuromuscular disorders with bulbar dysfunctions, malnutrition, therapy with corticosteroids, cytostatics or immunosuppressant, mental retardation, gastro-oesophageal reflux disease, bronchial obstruction, inability to cough, sepsis ${ }^{(2)}$.

$\underline{\text { Physiology }}$

In $90 \%$ of cases polymicrobial bactrial are found, From anaerobic bacteria in lung abscess predominant isolates being gram-negative Bacteroides fragilis, Fusobacterium capsulatum and Necrophorum, grampositive anaerobic streptococcus and microearophillic streptococci.From aerobic bacteria predominant isolates in lung abscess being Staphylococcus aureus lik ; methicillin resistant Staphylococcus aureus (MRSA)], Streptococcus pyogenes and pneumonia, Klebsiella pneumonia, Pseudomonas aeruginosa, Haemophilus influenza (type B), Acinetobacter spp, Escherichia coli, and Legionela ${ }^{(3)}$.

Anaerobic bacteria have been for decades the most dominant type of bacteria in lung abscess with Streptococcus spp (Streptococcus pneumonia serotype 3 i Streptococcus anginosus complex).During the last decade the most isolated type bacteria in lung abscess, especially in Taiwan has been Klebsiella pneumonia, so it is very important to have specific antibiotic therapy for that type of bacteria Staphylococcus aureus is the most common isolated etiologic 
pathogen of lung abscess in children (4).

Etiologic pathogen for lung abscess might be, as well Mycobacterium spp, Aspergillus, Cryptococcus, Histoplasma, Blastomyces, Coccidoides, Entamoeba histolytica, Paragominus westermani.

Actinomyces and Nocardia asteroides are known as important etiologic pathogens of lung abscess and they require a longer duration (6 months) of antibiotic administration.

Predictive parts of lung as common sites for lung abscess have been apical segment of lower lobe of right and sometimes of left lung, then lateral part of posterior segment of right upper lobeaxillary sub segment, and middle lobe in case of vomiting and aspiration in prone position-this is typically for alcoholic persons.
In $75 \%$ of all lung abscesses, they are located in posterior segment of right upper lobe or in apical segment of lower lobe of both lungs .

Etiological, abscesses occurred after oropharyngeal aspiration is localized in posterior segments of the lungs, and there are no patterns for hematological dissemination of lung abscesses. Initially, aspiration secretion is localized in distal parts of bronchi causing localized pneumonitis as in figure (2). 
Thi-Qar Medical Journal (TQMJ):Vol.(19), No.(1), 2020

Web Site: https://jmed.utq.edu.iq

Email:utjmed@utq.edu.iq

ISSN (Print):1992-92 18, ISSN (Online):1992-92 18

DOI: https://doi.org/10.32792/utq/utjmed/19/1/4/0

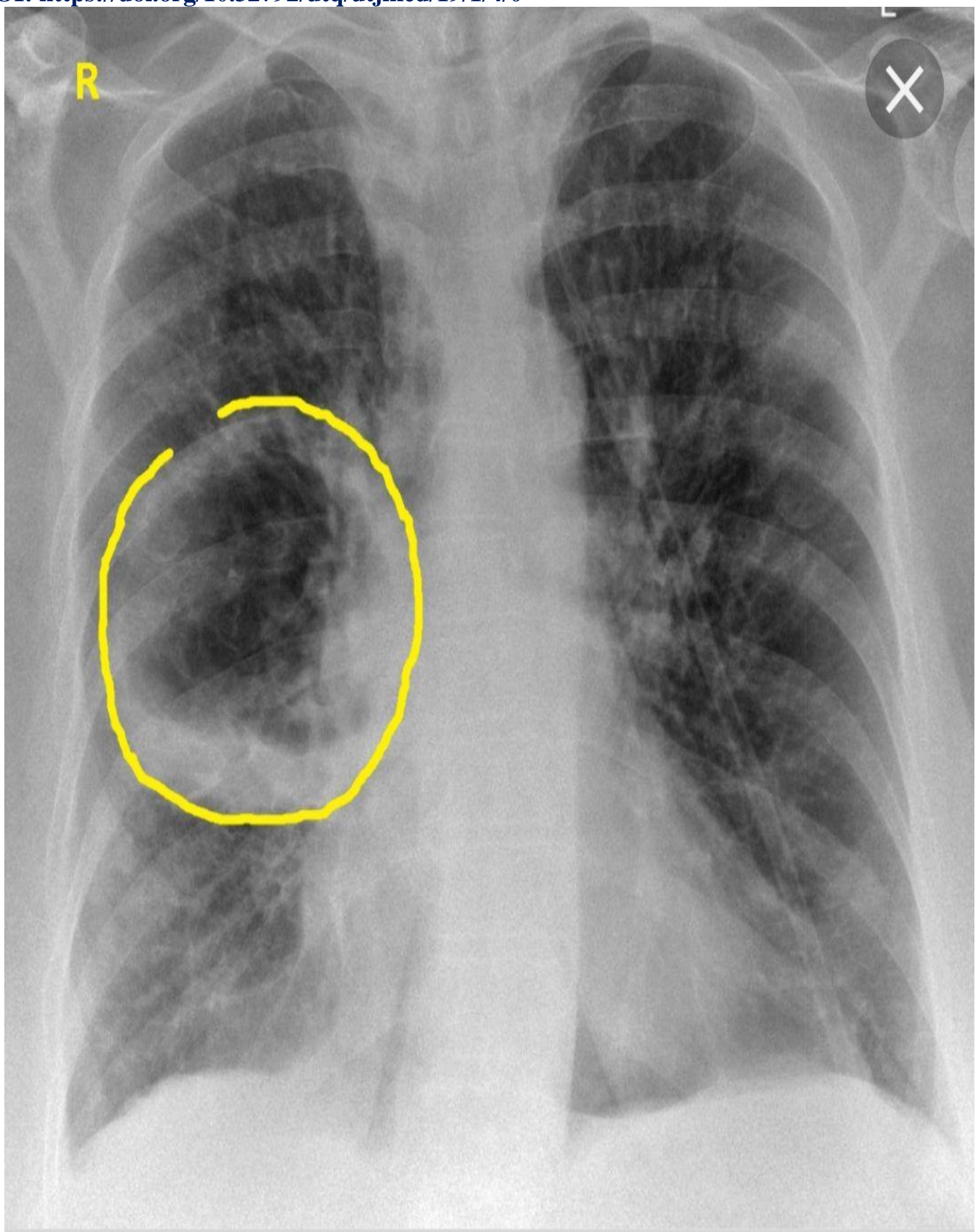

Figure(2):Represent chest X-ray of male patient suffer from lung abscess. 
In the next 24 to 48 hours (h) a larger area of inflammation with necrotic debris will develop.Invasive bacterial toxins, vasculitis, venous thrombosis and proteolytic enzymes from neutrophilic granulocytes will make a colliquative necrotic focus.

If the infective lung tissue affects visceral pleura, a pyopneumothorax or pleural emphysema will develop. In case of adequate antibiotic therapy and good immunologic status of patient, the chronic inflammatory reaction will circumscribe the process. In case of inadequate or delayed antibiotic therapy, poor general condition of patient, a sepsis can occur. If there is connection with the bronchus, necrotic detritus will empty the abscesses cavity and radiological sign of air-fluid level will occur.

In case of favorable outcome, a necrotic tissue will be eliminated by lysis and phagocytosis and granulation tissue will make a scar tissue.In case of adverse outcome, infection will spread around the lung tissue and pleural, mediastinal or cutaneous fistula can occur. In chronic abscess a necrotic detritus will be usually reabsorb and fibrosis and calcification can occur ${ }^{(\mathbf{4})}$.

\section{Signs and symptoms}

Early signs and symptoms of lung abscess cannot be differentiate from pneumonia and include fever with shivering, cough, night sweats, dispnea, weight loss and fatigue, chest pain and sometime anemia.

At the beginning cough is non-productive but when communication with bronchus appears, the productive cough is the typical sign. Cough remains productive, sometimes followed by hemoptysis. In patients with chronic abscess clubbing fingers can appear ${ }^{(\mathbf{5})}$.

\section{Differential diagnosis}

1. Excavating bronchial carcinoma (squamocellular or microcellular).

2. Excavating tuberculosis.

3. Localized pleural empyema.

4. Infected emphysematous bullae.

5. Cavitary pneumoconiosis.

6. Hiatus hernia.

7. Pulmonary hematoma.

8. Hydatid cyst of lung.

\section{Therapy}

Standard conservative therapy for lung abscess with anaerobic bacteria is clindamycin (600 mg IV on $8 \mathrm{~h}$ ) who showed in several clinical trials superiority to penicillin in terms of rates of response, duration of fever and time to resolution of putrid sputum.

Some types of Bacteroides species and Fusobacterium species can produce $\beta$ lactamase, so they are resistant to penicillin. About 15-20\% of anaerobic bacteria who are responsible for lung abscess formation are resistant to penicillin only, so alternative is combination of penicillin and clavulanate or combination of penicillin and metronidazole.

Metronidazole, as a single therapy does not appear to be particularly effective, due to poly microbial flora, presumably microaerophilic streptococci, such as Streptococcus milleri ${ }^{(\mathbf{6})}$.

Recommended combinations of antibiotics for lung abscess are combination of $\beta$-lactam with inhibitors of $\beta$-lactamase (ticarcilinclavulanate, ampicillin-sulbactam, 
amoxicillin-clavulanate, piperacilintazobactam), chloramphenicol, imipenem or meropenem, second generation of cephalosporins (cefoxitin, cefotetan), newer generation of fluoroquinolones-moxifloxacin, who showed to be as effective as combination ampicillin-sulbactam.

Macrolide

(erythromycin, clarithromycin, azithromycin) have very good therapeutic effect on polymicrobial bacteria in lung abscess, except on fusobacterium species. Vancomycin is very effective for grampositive anaerobic bacteria.therapeutic effect on poli microbial bacteria in lung abscess, except on fusobacterium species. Vancomycin is very effective for gram-positive anaerobic bacteria.

Abscess greater than $6 \mathrm{~cm}$ in diameter or if symptoms lasts more than 12 weeks with appropriate therapy, have little chances for only conservative healing, and surgical therapy should be considered, if general condition allows. Options for surgery are: chest tube drainage or surgical resection of lung abscess with surrounding tissue.

Endoscopic drainage of lung abscesses is described as an alternative to chest tube drainage and is performed during the bronchoscopy with usage of laser. It was recommended for the patients with poor general condition, coagulopathies and for the abscesses with central locations in lungs. One of the possible complication of these technique is a spillage of necrotic detritus in other parts of the lungs ${ }^{(7)}$.

\section{Aim of study}

To present the effectiveness of conservative treatment in lung abscess and the rare indication of surgery for such disease in AL-Hussein teaching hospital in Thi-Qar Governorate and to compare our study with other study in Iraq and abroad Iraq.

\section{Patients and methods}

This is a retrospective study of 50 patients suffering from lung abscess over a period of 5 years first May/2013 till first May 2018 in ALHussein teaching hospital in Thi-Qar governorate. On admission, an informative history was taken from every patient including age, sex, onset and nature of clinical features related to lung abscess. Base line data include patient demographics, present of combined diseases like hypertension ,DM, and other possible chronic diseases, presence of previous surgical operation and history of drug allergy, etc.

Every patient was exposed for clinical examination especially auscultation of chest. Different investigation were done including chest X-ray, chest CT scan and blood investigations, Most of our patients responded to conservative treatment and surgery via thoractomy was rarely indicated. Of course, a consent was taken from the patient and the family before the surgical procedure.

The patient was admitted and received heavy antibiotics intravenously. In addition, good hydration was provided and also mucolytics, analgesic and antipyretic drugs were given along with good physiotherapy. Management continued on an inpatient basis for an average of 7 days but there are several patients for 
ISSN (Print):1992-92 18, ISSN (Online):1992-92 18

DOI: https://doi.org/10.32792/utq/utjmed/19/1/4/0

whom admission for longer duration was indicated.

Follow up continued on an outpatient basis after relief of major signs and symptoms of lung abscess whether the treatment was by conservative measure and/or surgery.

\section{$\underline{\text { Results }}$}

Of the 50 cases of lung disease patients 24 males and 26 female aged from 10 years to 60 years and these sample obtained from AL-Hussein teaching hospital and we found the following result:

- $80 \%$ of the patient suffer from cough.

- $40 \%$ of the patient suffer from dyspnea.

- $8 \%$ of the patient suffer from hemoptysis

- Also, it was found that $90 \%$ of the patient suffer from fever and $20 \%$ of them suffer from weight loss and $10 \%$ have chest pain as in table number(1):

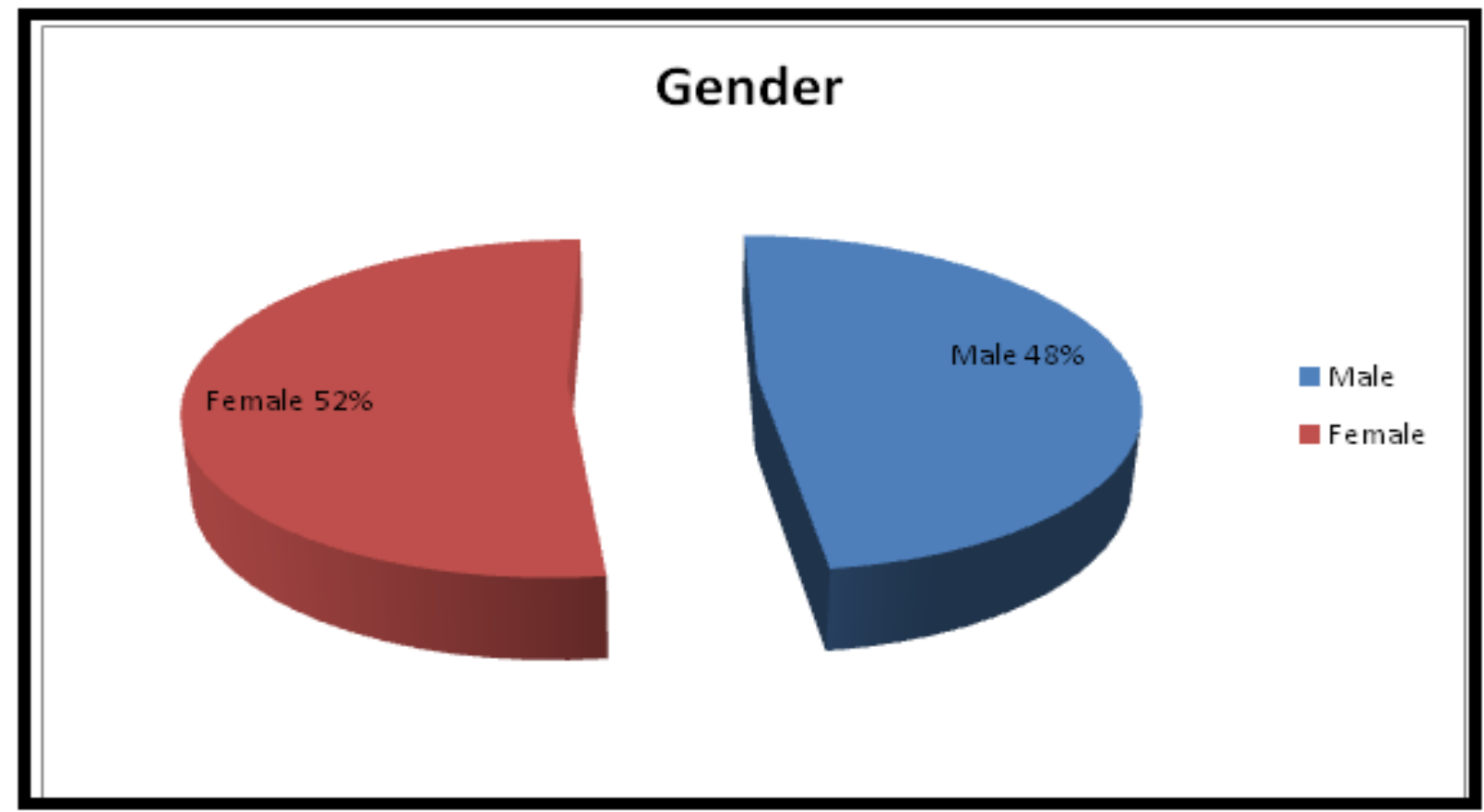

Figure ( No. 3): Sex of patients

The number of females( 26 patients) was slightly higher than males(24 patients) 
Web Site: https://jmed.utq.edu.iq

Email:utjmed@utq.edu.iq

ISSN (Print):1992-92 18, ISSN (Online):1992-92 18

DOI: https://doi.org/10.32792/utq/utjmed/19/1/4/0

Table ( No. 1): Correlate the patient age with the occurrence of lung abscess.

\begin{tabular}{|l|l|l|}
\hline Age of patient & NO. of patient & Percentage \\
\hline Less than 10 years & 10 & $20 \%$ \\
\hline $\mathbf{1 0 - 2 0}$ years & 5 & $10 \%$ \\
\hline $\mathbf{2 0 - 3 0}$ years & 5 & $10 \%$ \\
\hline $\mathbf{3 0 - 4 0}$ years & 5 & $10 \%$ \\
\hline $\mathbf{4 0 - 5 0}$ years & 5 & $10 \%$ \\
\hline $\mathbf{5 0 - 6 0}$ years & 10 & $20 \%$ \\
\hline More than 60 years & 10 & $20 \%$ \\
\hline Total & 50 & $100 \%$ \\
\hline
\end{tabular}

Table ( No. 2): Patient's complaints

\begin{tabular}{|l|l|l|}
\hline Presentation & No. of patient & percentage \\
\hline Cough & 40 & $80 \%$ \\
\hline Dyspnea & 20 & $40 \%$ \\
\hline Hemoptysis & 4 & $8 \%$ \\
\hline $\begin{array}{l}\text { Fever, } \\
\text { anorexia }\end{array}$ & 45 & $90 \%$ \\
\hline Wight loss & 10 & $20 \%$ \\
\hline Chest pain & 5 & $10 \%$ \\
\hline
\end{tabular}

Every patient was exposed for clinical examination especially auscultation of chest. Different investigation were done including chest X-ray, chest CT scan and blood investigations and we get the following results:

Table ( No. 3): The tests performed for the patient concerned:

\begin{tabular}{|l|l|l|}
\hline Investigation & No.of patient & percentage \\
\hline Chest X-ray & 50 & $100 \%$ \\
\hline Chest CT scan & 40 & $80 \%$ \\
\hline Bronchoscopy & 5 & $10 \%$ \\
\hline Routine blood investigation & 50 & $100 \%$ \\
\hline
\end{tabular}


Web Site: https://jmed.utq.edu.iq

Email:utjmed@utq.edu.iq

ISSN (Print):1992-92 18, ISSN (Online):1992-92 18

DOI: https://doi.org/10.32792/utq/utjmed/19/1/4/0

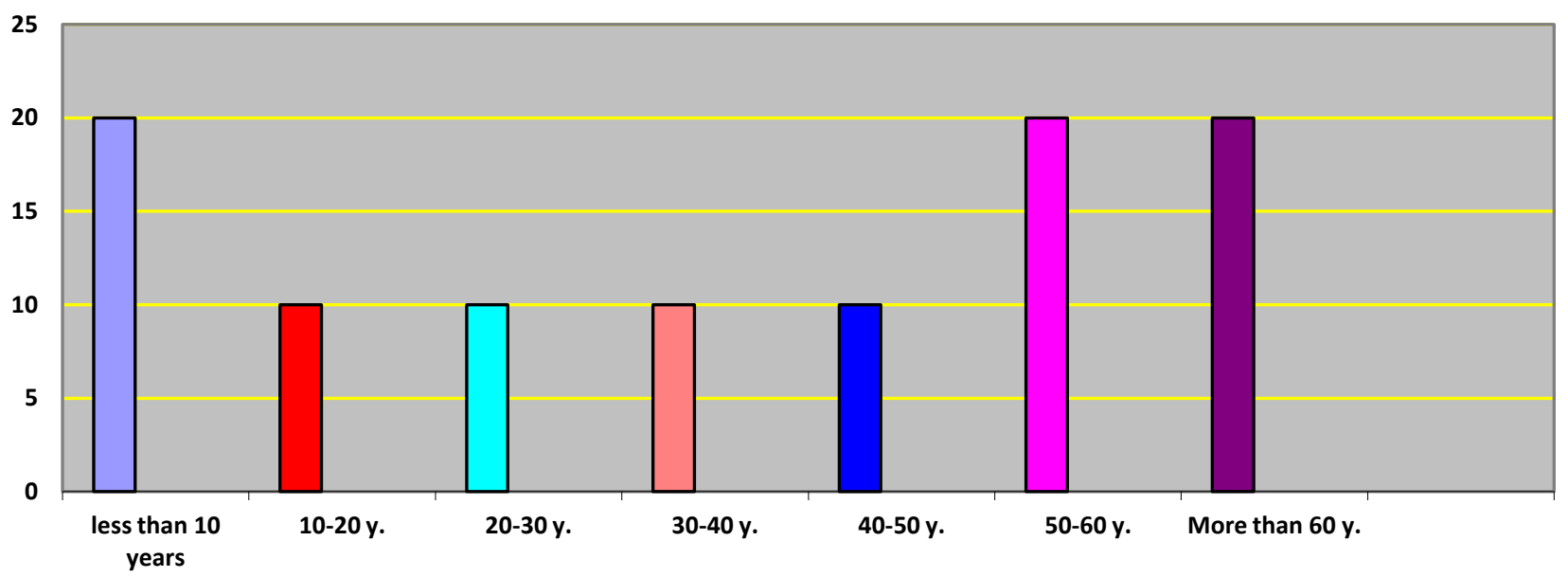

Figure ( No. 4): Correlation ( the percentage ) of the patient age with the occurrence of lung abscess.

Lung disease is more common in children than adolescence age groups and middle age but in elderly also incensed incidence of disease is noticed.

Table ( No. 4):Represent site of lung involved with abbesses:

\begin{tabular}{|l|l|l|}
\hline Site of lung & No. of patient & percentage \\
\hline Upper zone & 10 & $20 \%$ \\
\hline Middle zone & 20 & $40 \%$ \\
\hline Lower zone & 20 & $40 \%$ \\
\hline Total & 50 & $100 \%$ \\
\hline
\end{tabular}

Table ( No. 5):Represent the compares between the conservative measure and surgical operation performed for the patient concerned:

\begin{tabular}{|l|l|l|}
\hline Treatment & NO. of patient & percentage \\
\hline Conservative measure & 46 & $92 \%$ \\
\hline surgery & 4 & $8 \%$ \\
\hline
\end{tabular}




\section{Comaring between conservating measure and surgery}

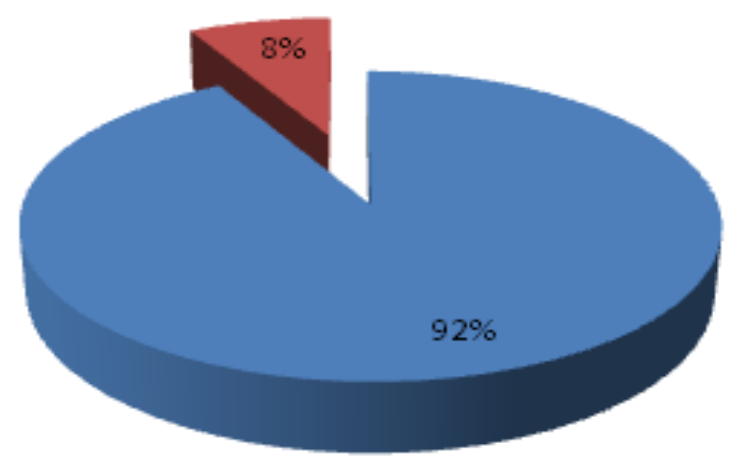

conservative measure $92 \%$

nurgery $8 \%$

Figure ( No. 5): Represent the compares between the conservative measure and surgical operation performed for the patient concerned

\section{Discussion:}

Twenty four patients were males and twenty six patient were females and both genders were affected equally approximately. This does not agree with the study of Jame ${ }^{(7)}$, in which the number of males(149 patients) highly exceed the number of females(35 females).

Morever, all ages were affected by lung abscess but the $5^{\text {th }}$ and $6^{\text {th }}$ decades were affected more than other age groups. This agrees with Jame's study in which the main age group affected was from the $4^{\text {th }}$ decade to the $6^{\text {th }}$ decade. The lower zones of both lungs were commonly affected $(40 \%)$ in our study and this goes with Jame's study.

Also most of our patients responded to conservative treatment (92\%) and surgery $(8 \%)$ was indicated in certain situations. This agrees with the study made by Jame in which $(89 \%)$ of the patients responded to conservative treatment and only(11\%) needed surgery.
Mortality was recorded in our study because of the malignancy mainly, but this fact does not agree with study made by Jame in which the mortality was recorded due to massive pulmonary hemorrhage, impaired immune defense, old age debility, bronchoplueral fistula with empyema or very large cavity. Accurate mortality rate could not be assessed accurately in our study due to absence of follow up. Prognosis was good in uncomplicated cases and in the absence of malignancy and this fact was different from that seen in Jame's study.

\section{Conclusions:}

1-Lung abscess is treated in most cases by conservative measures.

2-No mortality had been recorded in our study.

3-All patients received initially injectable antibiotics and the treatment may continue for several weeks to several 
Web Site: https://jmed.utq.edu.iq

\section{Email:utjmed@utq.edu.iq}

\section{ISSN (Print):1992-92 18, ISSN (Online):1992-92 18}

DOI: https://doi.org/10.32792/utq/utjmed/19/1/4/0 months.

4-Hemoptysis was recorded in several patients only

\section{Recommendation}

1-Treatment should always begin by injectable antibiotics.

2-Co-morbidity should be treated

simultaneously with lung abscess.

3-Malignacy should be put in mind in old aged people when there is no response to conservative measures.

4-Surgery is indicated only when conservative measure fail.

\section{References}

1..Robbins and cortan pathologic basis of diseases/respiratory sys.

2..Focal necrotizing pneumonia is a distinct entity from lung absces..2015

3. Lung abscess: update on microbiology and management. Am J Ther 2014

4. Bartlett JG. The role of anaerobic bacteria in lung abscess.

5. Modern history of surgical management of lung abscess: from Harold Neuhof to current concepts. Ann Thorac Surg.

6. Stock CT, Ho VP, Towe C, et al. Lung abscess. Surg Infect (Larchmt)2013;

7. Bartlett JG. Anaerobic bacterial infection of lung.

8. James Walters. Pus in the thorax: management of empyema and lung abscess.

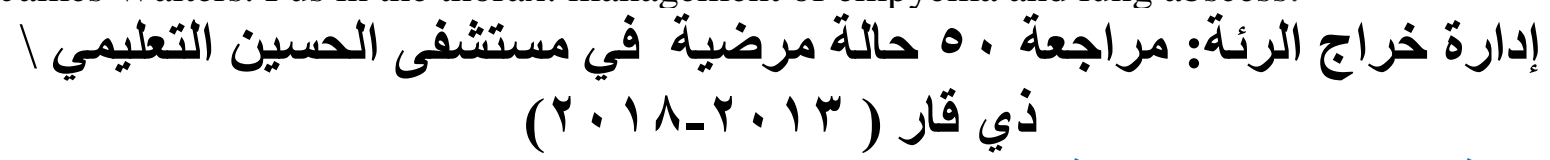

$$
\begin{aligned}
& \text { الاستثاذ المساعد الدكتّر احمد دفار عبدالامير } \\
& \text { الاكتور رياض محمد صالح } \\
& \text { الاكتور رافث رمثان حسين التميمي }
\end{aligned}
$$

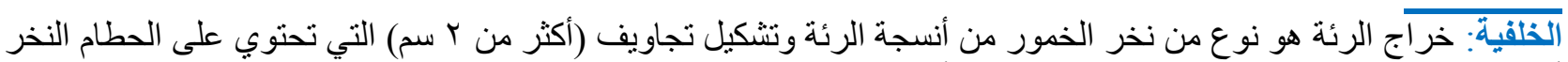

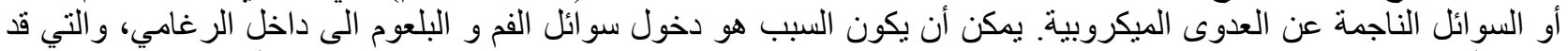

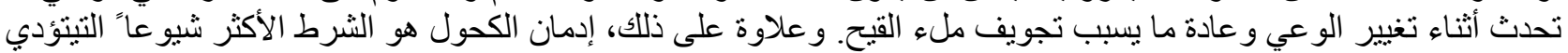
اللى حدوث خر اجات الرئة

الهوف: عرض فعالية العلاج التحفظي في خر اج الرئة و الإشارة النادرة لعملية جر احية لهذا المرض في مستشفى الحسين التعليمي

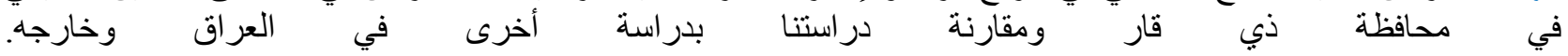

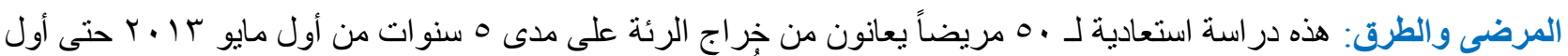

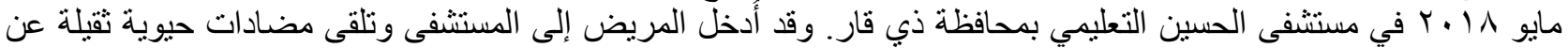

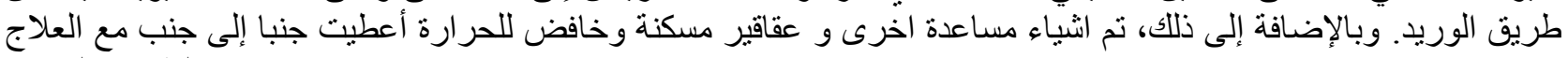
الطبيعي الجيد.

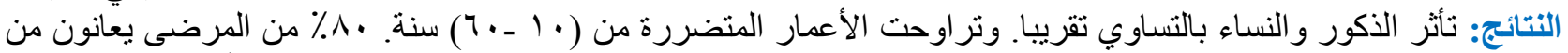

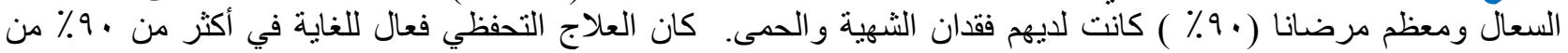

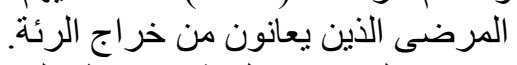

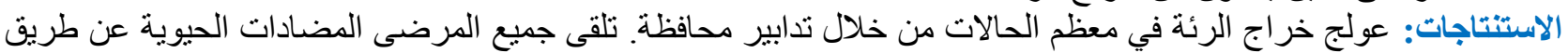

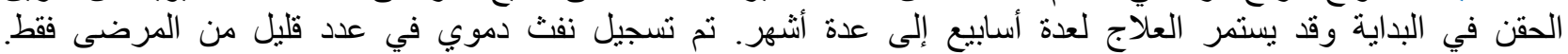

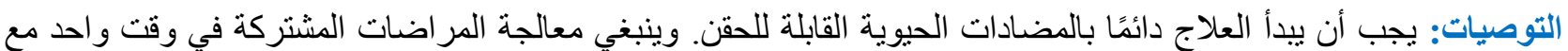
خر اج الرئة. وينبغي دائما استبعاد الأورام الخييثة خاصة في كبار السن. اما التندخل الجراحي فيتم اللجوء اليه فقط عندما تفنل التدابير المحافظة. 